\title{
Still no evidence that pathogen accumulation can revert the impact of invasive plant species
}

\author{
Mariana C. Chiuffo - Nahuel Policelli · Jaime Moyano • Agostina Torres • \\ Mariano A. Rodriguez-Cabal · Martín A. Nuñez
}

Received: 6 July 2017 / Accepted: 15 July 2017

(C) Springer International Publishing AG 2017

As do Flory et al. (2017), we recognize the potential consequences of pathogen accumulation for the dynamics of invaded plant communities. We also agree that pathogen accumulation is an important area of research requiring more attention. However, we are still puzzled by the paucity of data showing that pathogen accumulation can control invasive species populations. Flory et al. (2017) mentioned several examples, but they are mostly for native species, noninvasive species, agricultural settings, or artificial inoculation with pathogens (e.g., Harris et al. 2013).

The accumulation of pathogens on Bromus tectorum (Mordecai 2013) and Microstegium vimineun (Flory et al. 2011; Stricker et al. 2016) are the only examples of Flory et al. (2017) centered on invasive species in natural systems. Nevertheless, both species are still a very important problem in their invasive ranges (Freeman et al. 2014; Stark and Norton 2015; Tekiela and Barney 2017). Flory et al. (2017) discussed possible explanations for the lack of direct

Mariana C. Chiuffo and Nahuel Policelli contributed equally to this work.

M. C. Chiuffo · N. Policelli · J. Moyano ·

A. Torres - M. A. Rodriguez-Cabal · M. A. Nuñez $(\square)$

Grupo de Ecología de Invasiones, INIBIOMA,

Universidad Nacional del Comahue, CONICET, Avenida

de los Pioneros 2350, San Carlos de Bariloche, Río Negro,

Argentina

e-mail: nunezm@gmail.com evidence on the role of pathogens accumulation. They suggest this could be due to absence of historical interest in invasive species impact, or that it may take a very long time to observe positive impacts of pathogen accumulation on native ecosystems. We agree with these ideas but want to highlight that: (1) if long time lags are involved in the accumulation of pathogens it may be too late to reverse the impacts of invasive species, and (2) the lack of evidence may also be because control of non-native invasive species by pathogens may be a rare phenomenon.

We restate the key point in Policelli et al. (2017): the lack of evidence on pathogen accumulation controlling invasive populations calls for active management. As Flory et al. (2017) put clearly: "no waiting for pathogens to suppress invaders."

\section{References}

Flory SL, Kleczewski N, Clay K (2011) Ecological consequences of pathogen accumulation on an invasive grass. Ecosphere 2:1-12

Flory SL, Alba C, Clay K, Holt RD, Goss EM (2017) Emerging pathogens can suppress invaders and promote native species recovery. Biol Invasions. doi:10.1007/s10530-0171438-9

Freeman ED, Sharp TR, Larsen RT, Knight RN, Slater SJ, McMillan BR (2014) Negative effects of an exotic grass invasion on small-mammal communities. PLoS One 9:e108843 
Harris PT, Cannon GH, Smith NE, Muth NZ (2013) Assessment of plant community restoration following Tree-of-Heaven (Ailanthus altissima) control by Verticillium albo-atrum. Biol Invasions 15:1887-1893

Mordecai EA (2013) Despite spillover, a shared pathogen promotes native plant persistence in a cheatgrass- invaded grassland. Ecology 94:2744-2753

Policelli N, Chiuffo MC, Moyano J, Torres A, Rodriguez-Cabal MA, Nuñez MA (2017) Pathogen accumulation cannot undo the impact of invasive species. Biol Invasions. doi:10. 1007/s10530-017-1439-8
Stark JM, Norton JM (2015) The invasive annual cheatgrass increases nitrogen availability in 24-year-old replicated field plots. Oecologia 177:799-809

Stricker KB, Harmon PF, Goss EM, Clay K, Luke Flory S (2016) Emergence and accumulation of novel pathogens suppress an invasive species. Ecol Lett 19:469-477

Tekiela DR, Barney JN (2017) Co-invasion of similar invaders results in analogous ecological impact niches and no synergies. Biol Invasions 19:147-159 